\title{
Śmierć katolikosa Ambrożego i jej wpływ na losy Gruzińskiej Cerkwi Prawosławnej w opinii Zygmunta Mostowskiego*
}

Zarys treści: W artykule zaprezentowano raport Zygmunta Mostowskiego, polskiego konsula w Tyflisie, na temat sytuacji w Gruzińskiej Cerkwi Prawosławnej po śmierci katolikosa Ambrożego; przedstawiono najważniejsze wnioski, które wyciągnął polski dyplomata z wydarzeń związanych z konfliktem na łonie Cerkwi gruzińskiej, spowodowanych jej infiltracją przez radzieckie służby specjalne.

Outline of content: The article presents a report written in April 1927 by Zygmunt Mostowski, a Polish consul in Tbilisi, on the situation in the Georgian Orthodox Church after the death of Catholicos-Patriarch of All Georgia Ambrosius, and discusses the most important conclusions drawn by the Polish diplomat from the events related to the conflict within the Georgian Orthodox Church resulting from its infiltration by the Soviet special services.

Słowa kluczowe: katolikos Ambroży, Gruzja, Zygmunt Mostowski, Gruzińska Cerkiew Prawosławna, polska dyplomacja

Keywords: Ambrosius, Georgia, Zygmunt Mostowski, Georgian Orthodox Church, Polish diplomacy

W archiwum będącym częścią Instytutu Polskiego i Muzeum im. gen. Sikorskiego w Londynie (20 Prince’s Gate, London, SW7 1PT) na odcinku o długości ok. półtora kilometra ciągną się półki, na których przechowuje się różnorakie dokumenty historyczne. Większość z nich dotyczy okresu II wojny światowej i uczestnictwa w niej Polski. Cześć zgromadzonego materiału związana jest z działalnością polskich misji dyplomatycznych, w tym i ambasady Polski w Londynie w okresie międzywojennym. Z powodu strategicznego znaczenia tej placówki spływały do niej informacje

* Artykuł powstał dzięki otrzymaniu przez autora stypendium Fundacji z Brzezia Lanckorońskich. 
$\mathrm{z}$ innych polskich przedstawicielstw, m.in. z konsulatu generalnego $\mathrm{w}$ Tyflisie ${ }^{1}$. Pisma otrzymane z Kaukazu przechowywane są w archiwum w zespole: Ambasada $\mathrm{RP}$ w Londynie, nr A.12P, w podzespole nr 11, teczce nr 3, zatytułowanej „Rosja Sowiecka - Raporty polityczne i informacyjne z Konsulatów w Leningradzie, Mińsku i Tyflisie”. Wśród nich znajduje się referat: „W sprawie zgonu katolikosa Ambrożego i rozłamu w gruzińskiej cerkwi prawosławnej”, sporządzony przez Zygmunta Mostowskiego. Polski dyplomata był konsulem I klasy i szefem konsulatu w Tyflisie w latach 1926-1931.

Podpisując układ pokojowy w Rydze w 1921 r., kończący wojnę z Rosją Radziecką, polska delegacja nie zgodziła się na rozciągnięcie jego postanowień na Zakaukazie. Tym sposobem Polska nie uznawała bolszewickich podbojów na tym obszarze, ale jednocześnie mieszkający tam Polacy nie zostali objęci warunkami repatriacji przewidzianymi przez umowę ${ }^{2}$. Oficjalnie rozciągnięto jej postanowienia na Zakaukazie w 1923 r., kiedy Polska notyfikowała powstanie Związku Socjalistycznych Republik Radzieckich. Z kolei sprawy konsularne uregulowane zostały szczegółowo przez podpisaną w 1924 r. polsko-radziecką konwencję konsularną, w której całe terytorium ZSRR potraktowane zostało jako jeden organizm. Zgodnie z ustaleniami Polska miało prawo otworzyć konsulat w Leningradzie, Chabarowsku i Kijowie, natomiast ZSRR - w Łodzi i we Lwowie. Oprócz tego, w przypadku powstania radzieckiego konsulatu generalnego w Gdańsku, strona polska mogła otworzyć analogiczną placówkę w Tyflisie. Stało się tak dwa lata po podpisaniu konwencji - w 1926 r. Głównym zadaniem pracowników polskiego konsulatu była opieka nad miejscowymi Polakami, których, zgodnie z rezultatami spisu powszechnego z 1926 r., mieszkało na Zakaukaziu 6324³. Drugim ważnym zadaniem było utrzymanie odpowiednich stosunków z władzami Zakaukaskiej Socjalistycznej Federacyjnej Republiki Radzieckiej i zbieranie o niej informacji o charakterze polityczno-gospodarczym. Było to konsekwencją takiego rozmieszczenia przez polskie władze sieci przedstawicielstw dyplomatycznych w ZSRR, aby te utworzyły, na miarę możliwości, komplementarne punkty informacyjne na temat wschodniego sąsiada ${ }^{4}$. $Z$ tej przyczyny pracownicy przedstawicielstwa w Tyflisie sporządzali notatki, które były ważne z polskiego punktu widzenia, zwłaszcza dotyczące stabilności władzy bolszewików w ZSRR i stosunku do niej różnych grup społecznych. Były to bowiem kwestie pozostające w ścisłym centrum zainteresowań politycznych decydentów z Warszawy.

Właśnie z powyższej perspektywy należy rozpatrywać przyczyny powstania dokumentu „W sprawie zgonu katolikosa Ambrożego i rozłamu w gruzińskiej

1 W 1936 r. nazwę miasta zmieniono na Tbilisi.

2 W. Materski, Gruzja, Warszawa 2000, s. 287.

3 Всесоюзная перепись населения 1926 года, http://demoscope.ru/weekly/ssp/ussr_nac_26. php?reg=5 (dostęp: 06.01.2016).

4 W. Materski, Polsko-radziecka konwencja konsularna z 18 lipca 1924 roku, „Dzieje Najnowsze” 4 (1973), s. 65-66. 
cerkwi prawosławnej” w kwietniu 1927 r. (data dzienna nie została zapisana). Referat przesłano w dwóch egzemplarzach do Ministerstwa Spraw Zagranicznych $\mathrm{w}$ Warszawie, a po jednym egzemplarzu otrzymało poselstwo $\mathrm{w}$ Moskwie ${ }^{5}$ i przedstawicielstwo dyplomatyczne w Londynie ${ }^{6}$. Do tej ostatniej placówki dotarł 23 maja. Opatrzono go gryfem „ściśle tajne”.

Dokument rozpoczyna się opisem zasług Ambrożego ${ }^{7}$ związanych z jego walką o zachowanie niezależności Gruzińskiej Cerkwi Prawosławnej. Z. Mostowski napisał, że „dnia 26 marca $z_{m a r ł}{ }^{8} \mathrm{w}$ Tyflisie powszechnie znany obrońca niezawisłości gruzińskiego kościoła prawosławnego - katolikos Gruzji - Ambroży”. Zgodnie z jego słowami zmarły był patriotą, człowiekiem o wielkich zaletach umysłowych i dobrym sercu. Swoją uczciwość wielokrotnie przejawiał w czasach ciężkiej niedoli, w jakiej znalazła się jego ojczyzna. Polski dyplomata podkreślił, że świadectwo obywatelskiej odwagi i prawość charakteru Ambrożego ujawniła się chociażby w tym, że zwrócił się on do uczestników konferencji genueńskiej ${ }^{9}$ z protestem przeciwko agresji bolszewickiej w 1921 r. czy też że stale przeciwstawiał się, z właściwą sobie stanowczością, bezprawiom i okrucieństwom nowych władz radzieckich, rabunkom mienia kościelnego itp.

W dalszej części raportu dyplomata podkreślił, że Ambroży cieszył się dużą popularnością, z którą musieli się liczyć nawet jego wrogowie. Niemniej jednak z powodu swoich śmiałych wypowiedzi i niepodporządkowaniu się władzom, katolikos przez kilka miesięcy był przetrzymywany w areszcie domowym, a następnie został uwięziony przez Czeka (Wszechrosyjską Komisję Nadzwyczajną do Walki z Kontrrewolucją, Spekulacją i Nadużyciami Władzy ${ }^{10}$ wraz z kilkoma członkami

${ }^{5}$ Polskie poselstwo w Moskwie podniesiono do rangi ambasady w $1934 \mathrm{r}$.

${ }^{6}$ Do 1929 r. Polskę w Wielkiej Brytanii reprezentował dyplomata w randze ministra, a następnie $\mathrm{w}$ randze ambasadora.

7 Ambroży, właśc. Wissarion Chelaja (1861-1927), był znany m.in. z powodu starań o przywrócenie autokefalii Gruzińskiej Cerkwi Prawosławnej i negatywnego stosunku do bolszewików.

8 Data śmierci Ambrożego podana przez Z. Mostowskiego różni się od oficjalnej daty śmierci katolikosa, tj. 29 marca 1927 r.

9 Chodzi o memorandum, które 7 lutego 1922 r. Ambroży przesłał uczestnikom konferencji genueńskiej. Opisał w niej warunki panujące w Gruzji po zajęciu jej przez Armię Czerwoną. Oprócz tego $\mathrm{w}$ dokumencie wyraził protest $\mathrm{w}$ imieniu narodu gruzińskiego przeciwko radzieckiej okupacji. Katolikos wezwał cywilizowany świat do reakcji na agresywną politykę reżimu bolszewickiego; patrz: L. Tchantouridze, Russian Annexes Georgia. Georgian Patriarch's Letter to the 1922 Genoa Conference, „Canadian Journal of Orthodox Christianity” 3 (2008), nr 3, s. 67-73.

${ }_{10}$ Katolikos Ambroży i członkowie Rady zostali aresztowani w lutym 1923 r. 10 marca 1924 r. w Tyflisie rozpoczął się proces sądowy księży oskarżonych o kontrrewolucyjne przestępstwa, których większość polegała na ukrywaniu majątku cerkiewnego przed konfiskatą. W toku procesu dodano oskarżenia związane m.in. z apelem katolikosa do uczestników konferencji genueńskiej o pomoc w obronie Gruzji przed wojskami bolszewickimi. 19 marca sąd skazał katolikosa Ambrożego za „sporządzenie fałszywych pogłosek, ukrycie przedmiotów wartościowych i sprzeciwianie się władzy" na dziewięć lat więzienia i konfiskację majątku; zob. Святой исповедник Амвросий (Хелая) перед коммунистическим правосудием. Сборник составила, предисловием и комментариями снабдила Динара Дарсалия, Тбилиси (b.d.). 
Rady Patriarszej. Z. Mostowski wymienił w tym kontekście biskupa Cincadze ${ }^{11}$, biskupa Pawła ${ }^{12}$ i księdza Mirianaszwilego ${ }^{13}$. Polak zaznaczył także, że jednocześnie $\mathrm{z}$ aresztem cerkiewnych dostojników władze radzieckie zdecydowały się na zamknięcie i opieczętowanie wielu gruzińskich świątyń ${ }^{14}$. Z. Mostowski informował w raporcie, że zgodnie z postanowieniem Sądu Ludowego wszyscy wymienieni księża zostali skazani na długie lata ciężkiego więzienia. Jednakże już w 1924 r., po stłumieniu powstania w Gruzji ${ }^{15}$, Centralny Komitet Wykonawczy ZSRR na sesji odbywającej się w Tyflisie zdecydował o wypuszczeniu uwięzionych osób duchownych ${ }^{16}$, zezwolił im na powrót do swoich biskupstw i objęcie wcześniej zajmowanych stanowisk, a zamknięte cerkwie nakazał ponownie otworzyć. Zdaniem dyplomaty amnestia była spowodowana uwzględnieniem przez komunistów tego, że prześladowania katolikosa Ambrożego i oddanego jemu duchowieństwa wywoływały wrogie nastawienie do władzy radzieckiej zarówno w środowisku gruzińskiej inteligencji, jak i wśród robotników.

Zgodnie z relacją polskiego dyplomaty bolszewicy nie byli w stanie za pomocą represji ograniczyć wpływy katolikosa Ambrożego, mającego ogromny moralny autorytet, ani zrealizować swoich celów zarówno w sprawach religijno-wyznaniowych, jak i w polityce wewnętrznej. W związku z tym władza radziecka z Moskwy rozpoczęła bardzo podstępną i perfidną kampanię zmierzającą do likwidacji niezależności i podporządkowania centralnym organom państwowym Gruzińskiej Cerkwi Prawosławnej. Bolszewicy wybrali taki sposób działania, aby formalnie pozostawić katolikosa Ambrożego na stanowisku, ale jednocześnie pozbawić go realnej władzy przy pomocy nieustannych intryg, prześladowań i wzniecania waśni wśród wiernych mu księży. Tym sposobem starali się doprowadzić do rozłamu wśród duchowieństwa i zniszczenia jedność Gruzińskiej Cerkwi Prawosławnej, aby w rezultacie ostatecznie zlikwidować jej autokefalię ${ }^{17}$. Tymi metodami, zdaniem Z. Mostowskiego, komuniści chcieli powrócić do sytuacji, która zapanowała na początku XIX w. po przyłączeniu Gruzji do Rosji. Wtedy to jedną z ważniejszych decyzji podjętych w ciągu kilku pierwszych lat przez władze rosyjskie było zlikwidowanie autokefalii i podporządkowanie Cerkwi gruzińskiej

11 Chodzi o Kalistrata Cincadze, który w 1932 r. został wybrany na katolikosa.

12 Chodzi o Pawła Dżaparidze, który w latach 1924-1930 był biskupem cilkańskim. W czasie aresztowania przez WCzK był archimandrytą.

${ }^{13} \mathrm{~W}$ dokumencie Z. Mostowski nieznacznie przeinaczył nazwisko i zapisał je w formie: Marjoniszwili.

14 Zgodnie z szacunkami w latach 1922-1923 w Gruzji zostało zamkniętych ok. 1200 cerkwi.

15 Antykomunistyczne powstanie w Gruzji miało miejsce na przełomie sierpnia i września 1924 r., rozpoczęło się 28 sierpnia. Tego dnia uformował się tymczasowy rząd gruziński na czele z Georgiem Ceretelim. Powstanie zostało stłumione do 5 września, w tym czasie zginęło ok. 3000 osób, następnie rozstrzelano dodatkowo ok. 12 tys. osób; А. Топтыгин, Неизвестный Берия, Москва 2002, s. 18.

16 Księża zostali zwolnieni z więzienia w marcu $1925 \mathrm{r}$.

17 W okresie radzieckim autokefalia Gruzińskiej Cerkwi Prawosławnej została utrzymana. 
rosyjskiemu Synodowi ${ }^{18}$. Przy tym nie nastąpiło to drogą kanoniczną, a przemocą. Od tego czasu aż do upadku caryzmu, nie tylko Gruzińska Cerkiew Prawosławna, ale wszystkie prawosławne cerkwie w Gruzji były podporządkowane egzarchowi wyznaczanemu przez Synod.

Dyplomata zaznaczył w raporcie, że sytuacja zmieniła się od razu po rozpoczęciu rewolucji rosyjskiej ${ }^{19}$. Wtedy to gruzińscy biskupi na odbywającym się w marcu 1917 r. zjeździe przywrócili autokefalię Gruzińskiej Cerkwi Prawosławnej ${ }^{20}$. Na kolejnych obradach, które miały miejsce w sierpniu tego samego roku, opracowano nowy status autokefalii Cerkwi i jednocześnie wybrano katolikosa, którym został biskup Kirion. Ten jednak umarł w lecie $1918 \mathrm{r} .{ }^{21} \mathrm{Na}$ nowego zwierzchnika Cerkwi obrano metropolitę tyfliskiego, Leonida ${ }^{22}$. Uroczyście ogłoszono go katolikosem 23 lutego 1919 r. na soborze w Mcchecie, byłej stolicy państwa gruzińskiego, która do czasów obecnych pozostaje religijnym centrum Gruzji ${ }^{23}$. Po śmierci Leonida $^{24}$ trzecim katolikosem został Ambroży ${ }^{25}$, któremu przypadła męczeńska rola obrońcy niezależności Gruzińskiej Cerkwi Prawosławnej przed zachłannymi zakusami centralnych władz radzieckich.

Zygmunt Mostowski w swoim raporcie podkreślił, że ostatnie lata życia Ambrożego były okresem cierpienia, spowodowanego fizycznym osłabieniem, długotrwałym przebywaniem $\mathrm{w}$ więzieniu, a także dokuczliwymi szykanami moralnymi i intrygami. Przyspieszyło to śmierć duchownego, wyczekiwaną przez

18 Gruzińska Cerkiew Prawosławna otrzymała autokefalię w połowie V w., uniezależniając się od Antiochii. W 1801 r. Gruzja (Królestwo Kartlii i Kachetii) została częścią Cesarstwa Rosyjskiego, a 21 czerwca 1811 r. Świątobliwy Synod odsunął od władzy katolikosa Antona II i zlikwidował ten urząd. Od tej pory do marca 1917 r. cerkiew w Gruzji posiadała status Gruzińskiego Egzarchatu Cerkwi Rosyjskiej. Pierwszym egzarchą był metropolita Warlaam (Eristawi).

19 Chodzi o rewolucję lutową z $1917 \mathrm{r}$.

2012 marca (25 marca wg starego stylu) na soborze w Mcchecie przedstawiciele Gruzińskiej Cerkwi Prawosławnej przywrócili autokefalię. W tym samym miesiącu rząd tymczasowy pod kierownictwem Georgija Lwowa uznał autokefalię. Nie uczyniła tego natomiast Rosyjska Cerkiew Prawosławna, wobec czego stosunki między obiema cerkwiami zostały przerwane do $1943 \mathrm{r}$., kiedy to Patriarchat Moskiewski uznał autokefalię Gruzińskiej Cerkwi Prawosławnej.

${ }^{21}$ Kirion II (Giorgi Sadzagliszwili) został wybrany na katolikosa na soborze, który odbył się we wrześniu 1917 r. w Tyflisie. Intronizacja odbyła się 1 października w Mcchecie. Kirion II nie umarł śmiercią naturalną, w końcu czerwca 1918 r. został zamordowany w swojej rezydencji w Martkopi, na wschód od Tyflisu; zob. V. Kiknadze, Krótki zarys życia i działalności katolikosa-patriarchy Kiriona II, w: Dokumenty klasztoru oo. kamedułów z Pożajska w Państwowym Archiwum Historycznym w Tbilisi, red. I. Czamańska, Poznań 2012.

${ }^{22}$ Leonid został wybrany na następcę zamordowanego Kiriona II 29 listopada 1918 r.

23 Zgodnie z legendą Mccheta została założona w 2. poł. I tysiąclecia p.n.e. przez Mcchetosa. W IV w. p.n.e. król Kartlii Parnawaz wybrał ją na swoją rezydencję. Status stolicy królestwa kartlijskiego Mccheta utraciła w końcu V w. n.e. na rzecz Tbilisi. Od V w. Mccheta była religijną stolicą Gruzji, gdzie znajdował się sobór katolikosa - Sweti Cchoweli.

${ }^{24}$ Leonid umarł 11 czerwca $1921 \mathrm{r}$. w czasie epidemii cholery.

25 Ambroży został wybrany na katolikosa 7 września 1921 r., a jego intronizacja odbyła się 14 października. 
jego zaciekłych wrogów z obozu bolszewickiego. Polski dyplomata zaznaczył, że w ostatnim czasie sędziwy katolikos ${ }^{26}$ był już niemal wyłącznie bierny, co wynikało z jego fizycznej niemocy i skrajnego wyczerpania nerwowo-psychicznego, spowodowanego sparaliżowaniem jego wszelkiej działalności przez bolszewików. Autor raportu zwrócił uwagę, że mimo wszystko katolikos cieszył się dużą popularnością, a całe społeczeństwo uważało go za skałę stojącą na straży niezawisłości Cerkwi narodowej, której członkowie stanowili do 90\% ludności kraju ${ }^{27}$.

Zdaniem Z. Mostowskiego komuniści, mimo znacznego ubezwłasnowolnienia zwierzchnika Cerkwi, nie byli w stanie zrealizować do końca swoich destrukcyjnych planów w najbliższym i oddanym katolikosowi otoczeniu. $Z$ tego też powodu zorganizowali oni w Kutaisie ${ }^{28}$ zebranie kilku biskupów, których udało się nowej władzy wciągnąć w orbitę swoich wpływów. Komuniści doprowadzili do tego, że wybrali oni nową radę katolikosa, a także nowego wicekatolikosa - biskupa Christofora Cickiszwilii ${ }^{29}$, który miał stać się posłusznym narzędziem w rękach bolszewików. Poprzedni wicekatolikos, Kalistrat Cincadze $^{30}$, został zastraszony i zmuszony do złożenia urzędu. W tym też czasie GPU ${ }^{31}$ zamknęło i opieczętowało kancelarię rady katolikosa wiernej Ambrożemu. Następnie, po zebraniu w Kutaisie i wyborze rady złożonej z sympatyków władzy radzieckiej, została przekazana do jej dyspozycji. W tej sytuacji, wobec tak jawnego pogwałcenia praw przysługujących katolikosowi Ambrożemu, nie zważając na swoją ciężką sytuację, zebrał on u siebie wszystkich biskupów na poufnym zebraniu. W ten sposób starał się zapobiec rozłamowi dotychczas solidarnego, zdaniem Z. Mostowskiego, gruzińskiego duchowieństwa, które z powodzeniem opierało się rozmyślnym intrygom skierowanym przeciwko niezawisłości Cerkwi gruzińskiej.

${ }^{26} \mathrm{~W}$ momencie śmierci Ambroży miał 66 lat.

27 Z. Mostowski w tym przypadku podaje zawyżone dane. Zgodnie ze spisem ludności przeprowadzonym w 1926 r., w Gruzji mieszkało ok. 2650000 ludzi, z których 67\% było Gruzinami, stanowiącymi najliczniejszą i główną grupę wiernych Gruzińskiej Cerkwi Prawosławnej. Nawet jeśli doliczyć do niej Osetyjczyków (4\% populacji republiki), Rosjan (3\%) i Abchazów (2\%), to wyjdzie, że w Gruzji ok. 76\% społeczeństwa należało do narodów i grup etnicznych, które tradycyjnie wyznawały prawosławie. Jednakże od tego wyniku należałoby odjąć szybko rosnącą grupę ateistów; zob. Всесоюзная перепись населения 1926 года, http://demoscope.ru/weekly/ ssp/ussr_nac_26.php?reg=5 (dostęp: 29.08.2016).

28 Od 1936 r. miasto nosi nazwę Kutaisi.

${ }^{29} \mathrm{~W}$ marcu 1922 r. Christofor Cickiszwili został biskupem urbniskim. W okresie aresztowania katolikosa Ambrożego, tj. od lutego 1923 r. do marca 1925 r., stał na czele Tymczasowego Zarządu Cerkiewnego. W kwietniu 1925 r. Ch. Cickiszwili otrzymał godność metropolity i został przeniesiony do biskupstwa abchaskiego. Po śmierci Ambrożego Cickiszwili został wybrany na katolikosa (Christofor III) i urząd ten sprawował do 1932 r.

${ }^{30}$ Kalistrat Cincadze był jednym z tych członków rady, którzy zostali aresztowani razem z katolikosem Ambrożym w 1923 r. Po śmierci Christofora III w 1932 r., Cincadze został wybrany na katolikosa (Kalistrat). Tytuł ten zachował do swojej śmierci w 1952 r.

${ }^{31}$ Oficjalna nazwa brzmiała: Państwowy Zarząd Polityczny przy Ludowym Komisariacie Spraw Wewnętrznych Rosyjskiej Federacyjnej Socjalistycznej Republiki Radzieckiej. Była to policja polityczna. 
Bezpośrednie źródło (polski konsul nie uściślił, kto nim był) poinformowało dyplomatę, że na poufnym zebraniu zorganizowanym przez Ambrożego prowadzono gorące spory na temat uznania nowego wicekatolikosa, Cickiszwilego. Debaty te nie doprowadziły jednakże do przyjęcia wspólnego stanowiska. Prócz tego pięciu biskupów, którzy byli głęboko dotknięci tym, że część uczestników spotkania uległa wpływom i intrygom komunistów, demonstracyjnie opuściło obrady. Ponadto trzech $\mathrm{z}$ nich, informował konsul, rozważało przejście na katolicyzm. Tymi wydarzeniami miała zostać głęboko dotknięta znaczna część inteligencji gruzińskiej, wśród której zamiar biskupów odnośnie do zmiany wyznania zyskał dużą popularność i poparcie. Jak napisał Z. Mostowski w raporcie, jego wiarygodne źródło zapewniało, że z całą pewnością można spodziewać się masowego przejścia na katolicyzm gruzińskiej inteligencji. Miałoby to stanowić protest przeciwko przeniknięciu wpływów komunistycznych do Gruzińskiej Cerkwi Prawosławnej. Dyplomacie wydawało się to możliwe i prawdopodobne, ponieważ, jak donosił, tendencję do przechodzenia na katolicyzm wśród gruzińskiej inteligencji potwierdzała statystyka ubiegłych lat, wykazująca dość poważny wzrost liczebności Gruzinów katolików. Jako przykład konsul przytoczył dane, zgodnie z którymi corocznie tylko w samym Tyflisie 20 osób spośród inteligencji gruzińskiej przechodziło na katolicyzm. W opinii Z. Mostowskiego była to bardzo duża liczba jak na miejscowe warunki, zwłaszcza jeżeli wziąć pod uwagę niewielką liczebność inteligencji w stosunku do innych warstw społecznych.

Autor raportu był przekonany, że nawet jeśli rozłam w Gruzińskiej Cerkwi Prawosławnej i potencjalne przejście na katolicyzm trzech biskupów nie pociągnie za sobą przejścia na katolicyzm prawie całej gruzińskiej inteligencji - jak informowało źródło - to na pewno skłoni do takiego kroku liczne jednostki z kręgów opozycyjnych wobec komunistów. Dyplomata podkreślił również, że nie ulega wątpliwości, iż te ważne wydarzenia na łonie Gruzińskiej Cerkwi Prawosławnej i śmierć katolikosa Ambrożego znacznie ułatwią elementom destrukcyjnym ich niebezpieczną pracę. Zaznaczył także, że Cerkiew gruzińska znajduje się w trudnym okresie przełomowym.

Zygmunt Mostowski był zdania, że najważniejszą sprawą stojącą przed Gruzińską Cerkwią Prawosławną było wybranie nowego katolikosa. W tym celu zwołany sobór miał odbyć się w czerwcu ${ }^{32}$. Konsul był przy tym przekonany, że centralne organy władz związkowych, partyjni działacze komunistyczni i znajdujące się pod ich wpływem rosyjskie duchowieństwo prawosławne dołożą wszelkich starań, aby osiągnąć swoje cele po śmierci katolikosa Ambrożego. To bowiem właśnie on, posiadając duży autorytet moralny i ogromną popularność, utrzymywał solidarność w kręgach duchowieństwa gruzińskiego, a także bronił skutecznie przez długi czas niezależności Cerkwi gruzińskiej.

\footnotetext{
32 Sobór odbył się 21 czerwca.
} 
Konsul zaznaczył, że w czasach carskich Cerkiew prawosławna, zarówno gruzińska, jak i rosyjska, była w Gruzji podporządkowana Synodowi, który wyznaczał spośród swoich członków egzarchę zarządzającego Cerkwią w jej bieżącej działalności ${ }^{33}$. Po ogłoszeniu przez Gruzję niepodległości i przywróceniu autokefalii Cerkwi gruzińskiej, katolikosowi Gruzji podporządkowali się wyłącznie Gruzini. Rosjanie nie uznali jego władzy nad sobą i w dalszym ciągu podlegali biskupom wyznaczonym przez moskiewskie władze duchowne ${ }^{34}$. Z. Mostowski stwierdził, że centralne władze radzieckie, realizując swoje plany pozbawienia Cerkwi gruzińskiej samodzielności, dla ułatwienia swoich zamierzeń poczyniły bardzo sprytne kroki przygotowawcze. W tym celu niemal niezwłocznie po zebraniu w Kutaisie i wyborze uległego wpływom bolszewickim wicekatolikosa, moskiewskie władze duchowne zarządziły specjalnym dekretem faktyczną jedność Cerkwi prawosławnej w Gruzji. Mianowicie prawosławni Rosjanie na mocy tego dokumentu zostali zaliczeni do Gruzińskiej Cerkwi Prawosławnej, a duchowieństwo rosyjskie zostało podporządkowane władzy zwierzchniej Cerkwi gruzińskiej. W ten sposób, pisał konsul, do posiadającej wszelkie oznaki Cerkwi narodowej został wprowadzony element lojalny wobec centralnych władz rosyjskich, podobnie jak miało to miejsce $\mathrm{w}$ dawnych czasach, kiedy ustanowiono podległość rosyjskiemu Synodowi.

Zdaniem polskiego dyplomaty zachowanie autokefalii Cerkwi gruzińskiej i tytułu katolikosa było w najwyższym stopniu niepożądane dla centralnych władz związkowych ze względu zarówno na politykę wyznaniowo-religijną, jak i całościową politykę wewnętrzną Związku Radzieckiego. Uzasadnił on swoją opinię tym, że władza katolikosa na Wschodzie była w gruncie rzeczy większa niż władza centralnych organów cerkiewnych w Moskwie. W przypadku zachowania tytułu katolikosa taki stan mógłby się utrzymać także w przyszłości, co nie byłoby wygodne dla komunistów. Z. Mostowski zaznaczył przy tym, że chociaż po ostatnich wydarzeniach Cerkiew gruzińska została de facto podporządkowana władzom w Moskwie, to nawet formalne zachowanie tytułu katolikosa uważane było z punktu widzenia polityki radzieckiej za rzecz niepożądaną i niebezpieczną.

Konsul uważał, że opierając się na powyżej przytoczonych informacjach, rezultaty zaplanowanego na czerwiec soboru, na którym powinien zostać wybrany nowy katolikos, wydawały się być problematycznymi. W jego opinii nie powinno być żadnych wątpliwości co do tego, że wierne autokefalii duchowieństwo gruzińskie,

${ }^{33}$ Egzarcha stoi na czele egzarchatu, tj. cerkiewnej jednostki administracyjnej, która wywodzi się z okresu istnienia Cesarstwa Bizantyjskiego. Obecnie egzarchatem zazwyczaj nazywa się okręgi znajdujące się poza głównym terytorium działania danej cerkwi. Wśród Gruzinów niezadowolenie powodował fakt, że oprócz pierwszego egzarchy - metropolity Warlaama - na stanowisko to wyznaczani byli biskupi, którzy nie byli Gruzinami.

${ }^{34}$ Biorąc pod uwagę twierdzenia Z. Mostowskiego, że Rosjanie w Gruzji nie podporządkowali się katolikosowi, przytoczone wcześniej dane o tym, że Gruzińska Cerkiew Prawosławna obejmowała 90\% mieszkańców Gruzji wydają się jeszcze bardziej przesadzone. 
współpracujące $\mathrm{z}$ gruzińską inteligencją, nie ulegnie łatwo i będzie prowadzić energiczną akcję w obronie narodowej Cerkwi gruzińskiej. W tym miejscu konsul ponownie powołał się na swoje źródła, zgodnie z którymi osoby znajdujące się pod wpływem centralnych organów nie ośmielą się jeszcze stanąć do otwartej konfrontacji i będą tylko dążyć do odroczenia wyboru katolikosa. Dopiero z czasem, kiedy doprowadzą do wzmocnienia swojej pozycji, jawnie podejmą działania zmierzające do likwidacji autokefalii.

Zdaniem Z. Mostowskiego taka niepewna postawa znajdującego się pod wpływem bolszewików duchowieństwa uwarunkowana jest w znacznym stopniu bardzo nieprzychylnym nastawieniem gruzińskiego społeczeństwa, przy tym nie tylko prawosławnego, do osób odpowiedzialnych za rozłam w Gruzińskiej Cerkwi Prawosławnej. Na potwierdzenie tego stanu rzeczy dyplomata przytoczył przykład wicekatolikosa Cickiszwilego, który wobec powszechnej niechęci do niego uznał swoją sytuację w Tyflisie na tyle niepewną, że wyjechał do Abchazji ${ }^{35}$. Dalej Z. Mostowski relacjonował, że stosunek społeczeństwa do duchownego był bardzo nieprzyjazny. Uzasadnił to pozyskanymi przypadkowo informacjami, zgodnie z którymi kilkakrotne próby wygłoszenia $\mathrm{w}$ różnych cerkwiach kazania przez Cickiszwilego zostały udaremnione. W soborze siońskim ${ }^{36}$ miano mu uniemożliwić odprawienie mszy pontyfikalnej poprzez schowanie niezbędnych szat i sprzętów kościelnych. Zdaniem konsula można było założyć, że w odwet za takie żywiołowe objawy przywiązania ludności gruzińskiej do swojej Cerkwi narodowej grupki komsomolców ze szczególną zawziętością urządzały we wszystkich cerkwiach tyfliskich w okresie świąt Wielkanocnych skandale, tańce itp., dopuszczając się gorszących ekscesów zwłaszcza w stosunku do kobiet.

Pod koniec raportu polski dyplomata zaznaczył, że nadzwyczaj istotny problem rozłamu w łonie Gruzińskiej Cerkwi Prawosławnej, podobnie jak wszystkie ważne wypadki z tym związane, łącznie ze śmiercią katolikosa Ambrożego, nie odbiły się nawet najmniejszym echem na łamach lokalnej prasy. Z. Mostowski poinformował, że sprawy te nie są poruszane także w rozmowach towarzyskich wśród miejscowej inteligencji, przynajmniej w obecności pracowników polskiego konsulatu. Uważał on, że prawdopodobnie był to skutek obawy przed organami „dbającymi o lojalność obywateli”, a także panującej opinii o Polakach jako o ludziach wyjątkowo niebezpiecznych, a przez to szczególnie dobrze pilnowanych przez radzieckie służby. Z. Mostowski przyznał, że tego poglądu nie był w stanie zmienić, jego zdaniem przede wszystkim dlatego, że miał on realne podstawy, przynajmniej w tym znaczeniu, że pracownicy polskiego konsulatu byli najpilniej obserwowani

35 Warto tu zaznaczyć, że Ch. Cickiszwili był jednocześnie metropolitą diecezji abchaskiej.

${ }^{36}$ Sioni jest jedną z najważniejszych cerkwi w Gruzji. Znajduje się ona w centrum Tbilisi. Do czasu zbudowania w 2004 r. Cmindy Sameby, Sioni była katedralnym soborem katolikosa. Nazwa cerkwi nawiązuje do góry Syjon w Jerozolimie, natomiast świątynia została poświęcona Zaśnięciu Najświętszej Bogurodzicy. 
ze wszystkich przedstawicieli państw obcych mających swoje przedstawicielstwa w Tyflisie. Sytuacja taka miała miejsce, mimo że Z. Mostowskiemu udało się nawiązać życzliwe stosunki, nie tylko oficjalne, ale także osobisto-towarzyskie z Karklinem ${ }^{37}$, pełnomocnikiem Ludowego Komisariatu Spraw Zagranicznych, jego zastępcą Batajtisem, a także z przedstawicielami sfer rządowych $\mathrm{z}$ innych instytucji. Konsul zaznaczył, że obserwacja prowadzona przez służby radzieckie nie osłabła, dlatego że pracowników polskiego konsulatu uznano za "niebezpieczny” element na obszarze działania placówki, tj. na terytorium republik zakaukaskich.

Zaprezentowany dokument świadczy o tym, że polska dyplomacja w latach 20. XX w. była zainteresowana procesami zachodzącymi w łonie Gruzińskiej Cerkwi Prawosławnej. W znacznym stopniu stanowiło to konsekwencję postrzegania przez Polskę Związku Radzieckiego jako największego zagrożenia dla jej bezpieczeństwa. Z tego powodu polscy dyplomaci zwracali szczególną uwagę na te czynniki, które potencjalnie mogły stanowić barierę dla wzrostu wpływów władzy komunistycznej w poszczególnych republikach związkowych. Za jeden z takich elementów, opozycyjnie nastawionych wobec centralnych władz w Moskwie, uważana była właśnie Gruzińska Cerkiew Prawosławna. Niemniej jednak można się zastanawiać, czy rzeczywiście Z. Mostowski był dobrze obeznany z sytuacją w Cerkwi gruzińskiej. Widać wyraźnie, że konsul pisał o gruzińskiej Cerkwi jak o jedności, którą tylko komuniści chcieli zniszczyć. Faktem jest, że najważniejsi duchowni jednogłośnie dążyli do przywrócenia autokefalii. Jednakże między nimi trwała bezwzględna wojna, co ujawniło się już przy wyborze pierwszego katolikosa w 1917 r. Było wówczas dwóch kandydatów: biskup Kirion i biskup Leonid. Niewielką liczbą głosów wygrał pierwszy z nich, ale obóz biskupa Leonida nie pogodził się z porażką. Rozpoczął wydawanie czasopisma otwarcie opozycyjnego wobec katolikosa, co było sytuacją wyjątkową w świecie prawosławnym ${ }^{38}$. Niespełna rok po wyborze, w czerwcu 1918 r., Kirion został zamordowany. Istnieją poszlaki świadczące o tym, że zabójca był związany ze stronnikami biskupa Leonida, który został nowym katolikosem. Władze mienszewickiej Gruzji bardzo szybko zamknęly śledztwo w sprawie śmierci Kiriona. Ewidentnie decydenci polityczni nie starali się doprowadzić do wyjaśnienia zabójstwa. Można założyć, że przyczyną była obawa, iż sprawa ta osłabi pozycję niedawno utworzonego państwa na arenie międzynarodowej, do czego mogło przyczynić się ujawnienie intryg w łonie Cerkwi narodowej. Po 1921 r. nowe władze bolszewickie nie wznowiły śledztwa, ponieważ nie miałyby

37 Chodzi o Łotysza Ottona Karklina. W latach 1924-1929 był on przedstawicielem Ludowego Komisariatu Spraw Zagranicznych przy Zakaukaskiej Socjalistycznej Radzieckiej Republice Federacyjnej. O. Karklin został aresztowany w styczniu 1938 r. i w październiku 1939 r. skazany na 10 lat obozu pracy; umarł w $1942 \mathrm{r}$.

38 Czasopismo nazywało się „sbscmo bơ̊y3 ““ (pl. „Nowe słowo”) i wydawano je w 1918 r. 
z tego żadnej korzyści. Z analizy raportu wynika, że Z. Mostowski nie orientował się w okolicznościach śmierci katolikosa Kiriona ${ }^{39}$.

Zauważalne jest, że polski dyplomata szczególnie zainteresowany był kwestią przejścia biskupów i gruzińskich intelektualistów na katolicyzm. Oczywiście, jeżeli takie zjawisko byłoby powszechne, to odpowiadałoby interesom politycznym Polski. Państwo polskie, jako najsilniejsze centrum katolicyzmu w Europie Środkowo-Wschodniej, upatrywało szansy zwiększenia swojego wpływu na arenie międzynarodowej, zwłaszcza na Wschodzie, poprzez wykorzystanie czynników religijnych. Zwraca przy tym uwagę zbyt silny akcent, który Z. Mostowski położył na przejście duchownych prawosławnych na katolicyzm. Ostatecznie żaden z gruzińskich biskupów nie zdecydował się na taki krok, a konwersja wśród inteligencji nie była zjawiskiem masowym, dotyczyła bowiem jednostek. $Z$ tego powodu przechodzenie na katolicyzm było sporadyczne i w konsekwencji nie mogło doprowadzić do żadnych poważniejszych następstw politycznych czy społecznych. Podstawowej przyczyny odstępstwa od prawosławia polski dyplomata upatrywał w infiltracji Cerkwi gruzińskiej przez radzieckie służby specjalne, co nie podobało się sporej części księży. Do czasów współczesnych nie przeprowadzono szczegółowych badań porównawczych dotyczących wpływów bolszewików na poszczególne grupy wyznaniowe w Gruzji. Szczególna waga, którą przykładali komuniści do podporządkowania sobie Cerkwi gruzińskiej w pierwszym okresie po ustanowieniu władzy radzieckiej, wynikała z jej dużego wpływu na społeczeństwo. Kościół katolicki w Gruzji w latach 20. XX w. stanowił marginalną siłę i nie znajdował się w centrum uwagi władz związkowych, zwłaszcza na Zakaukaziu. Z dużym prawdopodobieństwem można założyć, że w przypadku zwiększenia zainteresowania nim społeczeństwa gruzińskiego byłby infiltrowanym w podobnym stopniu, co Cerkiew prawosławna, a być może nawet większym, głównie z powodu jego hierarchicznej struktury i usytuowanie jego zwierzchnika, papieża, poza strefą wpływów bolszewików. W rezultacie Kościół katolicki na Zakaukaziu mógłby zostać poddany jeszcze większym represjom niż Cerkiew prawosławna, którą komuniści mogli sobie całkowicie podporządkować, włącznie z jej najważniejszymi decydentami.

39 Po 1991 r. i ogłoszeniu przez Gruzję niepodległości popularnym stała się teza, że Kiriona zamordowali bolszewicy. Jednakże nie ma żadnych dowodów, nawet pośrednich, mogących świadczyć o ich udziale w spisku. Bolszewicy nic nie zyskiwali na likwidacji Kiriona i jego zastąpieniu na urzędzie katolikosa przez Leonida. Ze śmierci Kiriona pożytek mieli przede wszystkim jego cerkiewni przeciwnicy. Tezę o tym, że zabójstwo katolikosa było wynikiem wewnętrznych konfliktów na łonie gruzińskiej cerkwi potwierdza także reakcja rządu mienszewickiego. Dążył on do jak najszybszego zamknięcia śledztwa i nie starał się o wyjaśnienie tego głośnego morderstwa. Można założyć, że gdyby w zabójstwo byli zamieszani bolszewicy, to rząd propagandowo wykorzystałby ten fakt przeciwko nim. Natomiast ujawnienie, że cała sprawa wynikała z konfliktu wśród gruzińskich księży negatywnie odbiłaby się na wizerunku państwa, które zaledwie miesiąc wcześniej ogłosiło niepodległość. 
Prognozy Z. Mostowskiego ostatecznie się nie sprawdziły i komuniści ani nie zlikwidowali autokefalii Gruzińskiej Cerkwi Prawosławnej, ani nie znieśli tytułu katolikosa. Sobór, na którym zaplanowano wybór nowego katolikosa po śmierci Ambrożego, odbył się zgodnie z wcześniejszymi ustaleniami. W czerwcu 1927 r. na zwierzchnika Cerkwi został wybrany Christofor III, który okazał się człowiekiem całkowicie zależnym od bolszewików. W okresie jego rządów zakończyła się konfrontacja duchownych z władzami radzieckimi, gdyż komuniści ostatecznie podporządkowali sobie całkowicie struktury Cerkwi gruzińskiej.

\section{The death of Catholicos Ambrosius of Georgia and its impact on the fate of the Georgian Orthodox Church in Zygmunt Mostowski's opinion}

\section{Abstract}

The article presents a report written by the Polish diplomat Zygmunt Mostowski on the death of Catholicos-Patriarch of All Georgia Ambrosius and its consequences for the future of the Georgian Orthodox Church. Ambrosius died in March 1927, when Mostowski was the head of the Polish consulate in Tbilisi (1926-1931). The report, prepared for the Polish Ministry of Foreign Affairs, is kept in the archives of the Polish Institute and Sikorski Museum in London. Mostowski focused mainly on the infiltration of the Georgian Orthodox Church by the Soviet special services; he warned against a possibility of conversion to Catholicism of several of the Georgian Church hierarchs (including few bishops), as well as of a large part of Georgian intellectuals. But the Polish diplomat's predictions did not come true and there were only some individual cases of conversion.

The presented document evidences the fact that in the 1920s the Polish diplomacy was interested in processes occurring within the Georgian Orthodox Church. In a large part it resulted from perceiving the Soviet Union as a major threat to the security of the Polish state. And for this reason Polish diplomats paid special attention to those factors that could block the increasing influence of the communist power in individual republics of the Soviet Union. And the Georgian Orthodox Church was regarded as one of such factors, opposing the central authorities in Moscow.

\section{Кончина католикоса Амвросия и ее влияние на судьбу Грузинской православной церкви согласно мнению Зыгмунта Мостовского}

\section{Аннотация}

В статье был представлен отчет Зыгмунта Мостовского на тему кончины католикоса Амвросия и возможных последствий этого происшествия для Грузинской православной церкви. 3. Мостовский в 1926-1931 гг. был начальником польского консульства в Тифлисе и кончина Амвросия, случившаяся в марте 1927 г., пришлась на период его работы в Грузии. Доклад дипломата, составленный для польского Министерства иностранных дел, хранится в архиве Польского института и Музея им. ген. Сикорского в Лондоне. 3. Мостовский сосредоточился, прежде всего, на инфильтрации советских спецслужб в Грузинскую православную церковь. Он также сделал сильный акцент на возможность 
перехода церковных сановников (включая нескольких епископов), как и большей части грузинской интеллигенции в католичество. Однако прогнозы польского дипломата не оправдались и случаи обращения были лишь единичными.

Представленный документ является доказательством того, что польская дипломатия в 20-х гг. XX в. была заинтересована в процессах, происходивих в лоне Грузинской православной церкви. В значительной степени это было результатом того, что в это время Польша воспринимала Советский Союз как самую большую угрозу своей безопасности. Из-за этого польские дипломаты обращали внимание на те факторы, которые потенциально могли представлять собой препятствие росту влияния коммунистической власти в отдельных союзных республиках. Одним из таких элементов, оппозиционно настроенных к центральным властям в Москве, считалась именно Грузинская православная церковь.

\section{Bibliografia}

\section{Źródło:}

Mostowski Z., „W sprawie zgonu katolikosa Ambrożego i rozłamu w gruzińskiej cerkwi prawosławnej", archiwum Instytutu Polskiego i Instytutu im. gen. Sikorskiego, zespół: Ambasada RP w Londynie, nr A.12P, podzespół nr 11, teczka nr 3: „Rosja Sowiecka - Raporty polityczne i informacyjne z Konsulatów w Leningradzie, Mińsku i Tyflisie”

\section{Opracowania:}

Kiknadze V., Krótki zarys życia i działalności katolikosa-patriarchy Kiriona II, w: Dokumenty klasztoru oo. kamedułów z Pożajska w Państwowym Archiwum Historycznym w Tbilisi, red. I. Czamańska, Poznań 2012

Materski W., Gruzja, Warszawa 2000

Materski W., Polsko-radziecka konwencja konsularna z 18 lipca 1924 roku, „Dzieje Najnowsze” 4 (1973)

Tchantouridze L., Russian Annexes Georgia. Georgian Patriarch's Letter to the 1922 Genoa Conference, „The Canadian Journal of Orthodox Christianity” 3 (2008), nr 3

Всесоюзная перепись населения 1926 года, http://demoscope.ru/weekly/ssp/ussr_nac_26. php?reg=5 [dostęp 06.01.2016];

Святой исповедник Амвросий (Хелая) перед коммунистическим правосудием. Сборник составила, предисловием и комментариями снабдила Динара Дарсалия, Тбилиси (bez daty wydania);

Топтыгин А., Неизвестный Берия, Москва 2002

Przemysław Adamczewski (ur. 1981), kaukazoznawca; absolwent stosunków międzynarodowych Uniwersytetu im. Adama Mickiewicza w Poznaniu; w 2010 r. otrzymał tytuł doktora za pracę poświęconą problemowi karabachskiemu w polityce Azerbejdżanu po 1991 r. (w 2011 r. praca wyróżniona w Konkursie o Nagrodę im. prof. Roberta Mrozewicza na najlepszą pracę doktorską w zakresie stosunków międzynarodowych i dyplomacji, organizowanym przez Collegium Civitas w Warszawie); w latach 2013-2015 pracował w Instytucie Historii i Etnologii im. Ivane Dżawachiszwili w Tbilisi i realizował projekt badawczy „Mitologizacja pamięci historycznej jako determinant konfliktów etnicznych na Kaukazie"; od 2016 r. pracuje w Instytucie Studiów Politycznych Polskiej Akademii Nauk (adprzem@op.pl). 